Original Research Paper

\title{
Proximate Chemical Analysis of Luncheon and Burger at Egyptian Markets
}

\author{
${ }^{1}$ Ali M. Ahmed, ${ }^{2}$ Takwa H. Ismail, ${ }^{3}$ Reham Abouelmaatti, ${ }^{2}$ Rehab E.M. Gaafar and ${ }^{4}$ Wael M.K. Elfeil \\ ${ }^{1}$ Department of Food Hygiene, Faculty of Veterinary Medicine, Suez Canal University, Ismailia, Egypt \\ ${ }^{2}$ Department of Food Hygiene, Animal Health Research Institute, Ismailia, Egypt \\ ${ }^{3}$ Key Laboratory of Animal Epidemiology and Zoonosis, Sharkia Vet. Directorate, \\ General Org. Vet. Services, Ministry of Agriculture, Egypt \\ ${ }^{4}$ Department of Avian and Rabbit Medicine, Faculty of Veterinary Medicine, Suez Canal University, Ismailia, Egypt
}

\author{
Article history \\ Received: 10-10-2019 \\ Revised: 31-01-2020 \\ Accepted: 22-05-2020 \\ Corresponding Author: \\ Rehab E.M. Gaafar \\ Department of Food Hygiene, \\ Animal Health Research \\ Institute, Ismailia, Egypt \\ Email: elsayed.scu@ gmail.com
}

\begin{abstract}
The inspection of the affirmed composition of meat products is a compulsory task order to protect the public benefits and health against adulteration. A total of 100 commercial meat products were purchased from different retail markets in Ismailia city for identifying their chemical criteria. The commercial meat products are beef luncheon, beef burger, chicken luncheon and chicken burger, 25 sample from each. The obtained results were compared with the Egyptian standards to estimate their acceptability. The mean values of moisture content $(\%)$ in the examined samples were 62.66, 61.02, 66.87 and 63.72 and the mean values of protein content (\%) were $8.50,11.54,12.45$ and 11.34 , respectively. The corresponding mean values of fat content (\%) were 5.25, 17.13, 4.65 and 8.26 and mean values of ash content (\%) were 3.07, 4.01, 3.40 and 3.17. The mean values of carbohydrate content $(\%)$ were $20.49,6.29,12.63$ and 13.49 and the mean values of meat content (\%) were 26.05, 47.16, 49.67 and 44.14 for beef luncheon, beef burger, chicken luncheon and chicken burger, respectively. The correlation between protein and meat content was positive and significant $(\mathrm{P}<0.01)$ while correlation between moisture and fat was negative and significant $(\mathrm{p}<0.01)$. Strict supervision and periodical inspection of meat products should be carried out to ensure compliance with legal and compositional standards.
\end{abstract}

Keywords: Burger, Luncheon, Meat Analysis, Chicken, Beef

\section{Introduction}

Adulteration is a serious meat safety and quality issue which becomes the focus of attention for the food industry and consumers in the last few decades (Ahmed et al., 2016). The high price of meat and passiveness of consumer safety warranty further encourage the sellers to substitute components with other replacers in the manufacturing of meat products (Roostita et al., 2014). The meat products adulteration can take many forms such as complete or partial omission or substitution of valuable constituents with undeclared alternatives to increase product bulk or weight or to make the product appears of better value than it is (Hargin, 1996).

The modern technology in different fields gives chance for the meat processors to produce new products in different shapes, easily handled, stored and rapidly used. Meat products are highly demanded due to high biological value, reasonable price and agreeable taste and easy during serving (Edris et al., 2012). Prime importance in the meat industry is assuring a good quality control of the products on the market, especially of meat products to avoid the problem of adulterated food. The qualities of raw materials as well as the additives used in the final products are very important for public health. Therefore, the use of low quality ingredients in the processing yields low quality meat products (Pearson and Gillette, 1996). Meat products adulteration can be done by many ways such as complete or partial absence of valuable constituents, whole or partial substitution of components with an undeclared alternative to increase bulk or weight or to improve value (Hargin, 1996). Increases in profitability may be 
achieved by adulteration to enhance the perceived quality of products, reduce manufacturing costs or for product extension purposes (Ahmed et al., 2016). The detailed information on the chemical and nutritional contents is essential for consumers in choosing meat products (Erwanto et al., 2012). Consequently, consumers have become more selective and more considered about the quality of the product (brand quality, consumer reviewer comments, authority frequent reports....etc.), which became a more significant factor in marketing meat products (Eman, 2009). The widespread of species adulteration in retail markets may be attributed to the inadequate meat inspection and the lack of suitable and affordable analytical methods. However, the ability to detect less desirable or objectionable species in meat products is important for people whose religious practices limit the types of meat they eat as Muslim communities who are particularly concerned about the meat they eat and the accurate labeling which is critical to detect the species that are considered not permissible to eat (Abdelmoety et al., 2019; Abouelmaatti et al., 2013; Farouk, 2013; Rady et al., 2020; Sultan et al., 2020). In addition to increased rate of adulteration with chicken mean, this may be associated with the poultry pathogen epidemiological situation in Egypt in the recent five years and emerging of new pathogens or new variant from old endemic pathogens which associated with increase mortalities in poultry farms either due to viral pathogen like infectious bronchitis, avian influenza, Newcastle virus (Ayoub et al., 2019; Diab et al., 2019; Elhady et al., 2018; Fawzy et al., 2019; Sedeik et al., 2018; Sultan et al., 2019a; 2019b) or bacterial pathogen like Pasteurella, e-coli and clostridium or parasite like coccidia (Eid et al., 2016; 2019; Elfeil et al., 2012; Enany et al., 2018). Thus, identifying the species of meat in the finished meat products is the main target to fulfil Halal requirement and Islamic regulations (Hamzah et al., 2014). Therefore; the chemical analysis is applied to ensure compliance with legal and compositional standards of some meat products.

\section{Materials and Methods}

Meat products quality is a critical subject and the need of further information about the composition of meat products is increased.

\section{Collection of Samples}

A total of 100 different commercial meat product samples (25 each of beef luncheon, beef burger, chicken luncheon and chicken burger) were randomly collected from local and high different retail markets located in Ismailia city and transferred under refrigeration to the central lab, faculty of veterinary medicine to determine their chemical profiles.

\section{Preparation of Samples}

All samples were prepared and examined according to the technique recommended by AOAC (2003).

\section{Determination of Moisture Content}

Moisture Content was carried using the drying hot air oven.

\section{Determination of Crude Protein Content}

Crude protein content was measured using the Kjeldahl digestion block KJELDATHERM and VAPODEST 50s distillation systems (C. Gerhardt GmbH and Co. KG Cäsariusstraße 97, 53639 Königswinter, Germany).

\section{Determination of Fat Content}

Fat Content was estimated using the SOXTHERM Manager, (cat. no. 13-0012, Gerdhart, Königswinter, Germany).

\section{Determination of Total Ash}

Ash content was measurement using a muffle furnace at $550^{\circ} \mathrm{C}$.

\section{Estimation of Total Carbohydrate Content}

Total carbohydrate content was calculated as Carbohydrate $\%=100-($ Protein $\%+$ Fat $\%+$ Water $\%+$ Ash\%).

\section{Calculation of Meat Content According to CCFRA (1999)}

Meat content calculated by the following equation:

Fat Free Meat Content $\%=\frac{\% \text { Total Nitrogen }-\% \text { Non }- \text { Meat Nitrogen }}{N F} \times 100$

Where:

- Total Nitrogen is the total amount of nitrogen originating from the samples

Non-Meat Nitrogen $=\%$ carbohydrate $\times \frac{C N F}{100}$

$(C N F=$ the carbohydrate nitrogen factor $=0.02)$

- $\quad \mathrm{NF}$ is the nitrogen factor with the appropriate type of meat for the conversion of the nitrogen content to meat content (The nitrogen factors sub - committee of the analytical methods committee of the Royal Society of Chemistry) 


\section{Statistical Analysis}

Data were statistical analysis using SPSS, Version 16.0 computer program (SPSS, 2007). Least Significant Differences (LSD) at $0.05 \%$ level between means were calculated. Correlations between protein and meat content, fat and moisture were performed.

\section{Results and Discussion}

The chemical analysis indicates the nutritive criteria of the examined meat products which is important for consumer health and acceptability.

\section{Moisture Content}

Data in Table 1 showed that the mean values of moisture were $62.66,61.02,66.87$ and $63.72 \%$ for beef luncheon, beef burger, chicken luncheon and chicken burger, respectively. No significant differences between beef luncheon and beef burger and between beef luncheon and chicken burger. But there are significant differences between chicken luncheon and all the other products.

These results are lower than those had been recorded by (Ali, 2011) in beef burger and by (Al-Bahouh et al., 2012) in chicken burger and similar to those obtained by (Edris et al., 2012) in beef burger and higher than those been recorded by (Edris et al., 2012) in beef luncheon and by (Prayson et al., 2008) in beef burger as well as by (Jecan et al., 2013), (Ahmad et al., 2015) and (Al-Dughaym and Altabari, 2010) in chicken burger.

As Egypt has its own legislative nutritive criteria for meat products, the samples were compared with the Egyptian standards (EOS, 2005) to estimate their acceptability. The percentages of the non-accepted samples for moisture were 52, 44, 100 and 0.0 for beef luncheon, beef burger, chicken luncheon and chicken burger, respectively (Table 1).

Multiple factors can affect the moisture content include fat percentage (inverse relationship), addition of water and non-meat ingredients and degree and type of processing and cooking. The moisture content of a meat product is important because of the properties of water, its interaction with other components in the product and its contribution to the chemical, biological and physical properties of foods (Cornejo and Chinachoti, 2003).

\section{Protein Content}

The mean values of protein $\%$ in the examined meat products were $8.50,11.54,12.45$ and 11.34 for beef luncheon, beef burger, chicken luncheon and chicken burger, respectively. There are significant differences between beef luncheon and the other products, while no significant differences between them (Table 2).

These results were consistent with previous reports of El-Tahan et al. (2006) in chicken luncheon (ElTahan et al., 2006). These results were much higher percentages had been reported by (Edris et al., 2012) in beef luncheon and beef burger and (El-Tahan et al., 2006) in chicken burger. On the other hand, these results were lower the results obtained by (Ali, 2011) in beef burger.

The percentage of the non-accepted samples for protein \% according to the Egyptian standards (EOS, 2005) which were 96, 84, 48 and 64 for beef luncheon, beef burger, chicken luncheon and chicken burger, respectively (Table 2). The low protein content of some meat products may be due to addition of improper meat cuts or the use of meat trimmings in preparation or substitution with non-meat components, since meat proteins are relatively more expensive than non-meat components (Lawrie, 1998). Many of the protein sources used in preparing commercial products used presently are partially replaced by non-meat protein source. In addition to lowering the cost, non-meat protein sources such as egg, whey protein and soy protein, are able to improve the flavour and texture of the product by increasing the fat and moisture binding ability (Kassem and Emara, 2010). Definitely, these ingredients decrease the production cost and also enhance sensory quality but could not fulfill the prescribed limit for proteins (Turhan et al., 2007).

Table 1: Mean values of moisture content in the examined meat product samples with their acceptability according to the Egyptian standards

\begin{tabular}{|c|c|c|c|c|c|c|}
\hline \multirow[b]{2}{*}{ Meat products } & \multirow[b]{2}{*}{ Mean \pm SE } & \multirow[b]{2}{*}{$\mathrm{EOS}^{*}$} & \multicolumn{2}{|c|}{ Accepted Samples } & \multicolumn{2}{|c|}{ Unaccepted Samples } \\
\hline & & & No. & $\%$ & No. & $\%$ \\
\hline Beef luncheon & $62.66 \pm 0.84^{\mathrm{ac}}$ & $\begin{array}{l}\text { Not more than } 60 \% \\
\text { EOS }^{*}(1114 / 2005)\end{array}$ & 12 & 48 & 13 & 52 \\
\hline Beef burger & $61.02 \pm 0.81^{\mathrm{c}}$ & $\begin{array}{l}\text { Not more than } 60 \% \\
\text { EOS* }^{*}(1688 / 2005)\end{array}$ & 14 & 56 & 11 & 44 \\
\hline Chicken luncheon & $66.87 \pm 0.44^{\mathrm{b}}$ & $\begin{array}{l}\text { Not more than } 60 \% \\
\text { EOS* }^{*}(1696 / 2005)\end{array}$ & 0.0 & 0.0 & 25 & 100 \\
\hline Chicken burger & $63.72 \pm 0.57^{\mathrm{a}}$ & $\begin{array}{l}\text { Not more than } 70 \% \\
\text { EOS* }^{*}(2910 / 2005)\end{array}$ & 25 & 100 & 0.0 & 0.0 \\
\hline
\end{tabular}

EOS $*=$ Egyptian Organization for Standardization (EOS, 2005)

Means with the same letter are not significant difference $(\mathrm{P}<0.05)$. 
Table 2: Mean values of protein content in the examined meat product samples with their acceptability according to the Egyptian standards

\begin{tabular}{|c|c|c|c|c|c|c|}
\hline \multirow[b]{2}{*}{ Meat products } & \multirow[b]{2}{*}{ Mean $\pm \mathrm{SE}$} & \multirow[b]{2}{*}{ EOS } & \multicolumn{2}{|c|}{ Accepted samples } & \multicolumn{2}{|c|}{ Unaccepted samples } \\
\hline & & & No & $\%$ & No & $\%$ \\
\hline \multirow[t]{2}{*}{ Beef luncheon } & $8.50 \pm 0.75^{\mathrm{a}}$ & Not less than $15 \%$ & & & & \\
\hline & & $\operatorname{EOS}^{*}(1114 / 2005)$ & 1 & 4 & 24 & 96 \\
\hline \multirow[t]{2}{*}{ Beef burger } & $11.54 \pm 0.71^{\mathrm{b}}$ & Not less than $15 \%$ & & & & \\
\hline & & EOS* $^{*}(1688 / 2005)$ & 4 & 16 & 21 & 84 \\
\hline \multirow{2}{*}{ Chicken luncheon } & $12.45 \pm 0.45^{\mathrm{b}}$ & Not less than $12 \%$ & & & & \\
\hline & & EOS* $^{*}(1696 / 2005)$ & 13 & 52 & 12 & 48 \\
\hline \multirow[t]{2}{*}{ Chicken burger } & $11.34 \pm 0.53^{\mathrm{b}}$ & Not less than $12 \%$ & & & & \\
\hline & & EOS* $^{*}(2910 / 2005)$ & 9 & 36 & 16 & 64 \\
\hline
\end{tabular}

EOS * = Egyptian Organization for Standardization (EOS, 2005)

Means with the same letter are not significant difference $(\mathrm{P}<0.05)$.

Table 3: Mean values of fat content in the examined meat product samples with their acceptability according to the Egyptian standards

\begin{tabular}{|c|c|c|c|c|c|c|}
\hline \multirow[b]{2}{*}{ Meat products } & \multirow[b]{2}{*}{ Mean \pm SE } & \multirow[b]{2}{*}{ EOS $^{*}$} & \multicolumn{2}{|c|}{ Accepted samples } & \multicolumn{2}{|c|}{ Unaccepted samples } \\
\hline & & & No & $\%$ & No & $\%$ \\
\hline \multirow[t]{2}{*}{ Beef luncheon } & $5.25 \pm 0.32^{\mathrm{a}}$ & Not more than $35 \%$ & & & & \\
\hline & & EOS* $^{*}(1114 / 2005)$ & 25 & 100 & 0.0 & 0.0 \\
\hline \multirow[t]{2}{*}{ Beef burger } & $17.13 \pm 1.58^{\mathrm{b}}$ & Not more than $20 \%$ & & & & \\
\hline & & $\operatorname{EOS}^{*}(1688 / 2005)$ & 16 & 64 & 9 & 36 \\
\hline \multirow{2}{*}{ Chicken luncheon } & $4.65 \pm 0.39^{\mathrm{a}}$ & Not more than $35 \%$ & & & & \\
\hline & & EOS* $^{*}(1696 / 2005)$ & 25 & 100 & 0.0 & 0.0 \\
\hline \multirow[t]{2}{*}{ Chicken burger } & $8.26 \pm 0.79^{c}$ & Not more than $15 \%$ & & & & \\
\hline & & EOS* $^{*}(2910 / 2005)$ & 25 & 100 & 0.0 & 0.0 \\
\hline
\end{tabular}

EOS * = Egyptian Organization for Standardization (EOS, 2005)

Means with the same letter are not significant difference $(\mathrm{P}<0.05)$

\section{Fat Content}

The mean values of fat $\%$ in the examined meat product samples were 5.25, 17.13, 4.65 and 8.26 for beef luncheon, beef burger, chicken luncheon and chicken burger, respectively. There was a significant difference between beef burger and all the other products and between chicken burger and all the other products, while there were no significant differences between beef luncheon and chicken luncheon (Table 3).

These results were relatively lower than found by (Edris et al., 2012) in beef luncheon and beef burger as well as (Al-Dughaym and Altabari, 2010) and (El-Tahan et al., 2006) in chicken burger and by (Ali, 2011) in beef burger. Similar results to that were obtained by (Jecan et al., 2013) in chicken burger and by (El-Tahan et al., 2006) in chicken luncheon. On the other hand, These results were lower results to that obtained by (Ahmad et al., 2015) and (Al-Bahouh et al., 2012) in chicken burger.

By comparing the results with the Egyptian Standards (EOS, 2005), 36\% of beef burger only were unaccepted based on their fat content as revealed in Table 3. The function of fat is mainly influencing the sensory quality of burgers, particularly its flavor (Suman and Sharma, 2003). Fat as a major food component is used for its sensory and physiological benefits that contribute to the flavor, taste and aroma/odor of the final products (Moghazy, 1999). From the present result, it was clear that the examined products contained low cost fat substitute that resulted in the production of low-fat products. The production of low fat meat product can be achieved by increase in the carbohydrates and added water content that does not affect the traditional full-fat flavor, taste and texture but reduce the formulation cost (Ibrahim et al., 2011). This trend toward production of low-fat meat product might be a result of adulteration and the trials of the industry to reduce the cost, which make their products non-conferment with the standard.

\section{Ash Content}

The mean values of ash \% in the examined meat products were $3.07,4.01,3.40$ and 3.17 for beef luncheon, beef burger, chicken luncheon and chicken burger, respectively. There were significant differences between beef burger and all the other products, no significant differences between beef luncheon and chicken burger and no significant differences between chicken luncheon and chicken burger.

The current results were lower the results obtained by (Edris et al., 2012) in beef burger as well as by 
(Al-Dughaym and Altabari, 2010), (Ramadhan et al., 2011) and (Al-Bahouh et al., 2012) in chicken burger. The current results were higher finding were reported by (Edris et al., 2012) in beef luncheon.

The percentages of the non-accepted samples for ash $\%$ according to the Egyptian standards (EOS, 2005) were 12, 52 and 84 for beef luncheon, chicken luncheon and chicken burger, respectively as shown in Table 4. Ashes represent the total minerals found in food such as sodium, phosphorus and iron, that can be contributed by the meat as raw material, salt and spices added (Fernández-López et al., 2006). The ash content in meat products not only depend on muscle minerals but also on the curing salt added (Kirk and Sawyer, 1991). The high ash content could be achieved by the addition of spices for seasoning, high fiber carbohydrate, starches, cereals, soya-protein and salt. Incorporation of mechanically deboned chicken meat might be another reason for increasing the ash content (Babji et al., 2000).

\section{Carbohydrate Content}

The mean values of carbohydrate $\%$ in the examined samples were 20.49, 6.29, 12.63 and 13.49 for beef luncheon, beef burger, chicken luncheon and chicken burger, respectively. There were significant differences between beef luncheon and all the other products and between beef burger and all the other products. But there were no significant differences between chicken luncheon and chicken burger (Table 5).
These results were nearly consistent with previous reports of (Ramadhan et al., 2011) in chicken burger. While current results were higher the results had been reported by (Abd-Elhak et al., 2014) in beef burger. However, these results were lower the results were obtained by (Babji et al., 2000) and (Al-Bahouh et al., 2012) in chicken burger.

The Egyptian Standards (EOS, 2005) of beef burger stated that carbohydrate should not exceed $10 \%$. The results showed that $20 \%$ of the samples were not in compliance with the Egyptian standards. Carbohydrates in burgers are mainly from the use of starches as ingredients. Starches, such as maize, tapioca, rice, potato and wheat, have been used as meat filler and water binder and this result could be due to the use of cheap ingredients like rusk, bread crumbs, cereal and soya protein (Joly and Anderstein, 2009).

\section{Meat Content}

The mean values of meat content $\%$ in the examined meat products were $26.05,47.16,49.67$ and 44.14 for beef luncheon, beef burger, chicken luncheon and chicken burger, respectively. There were significant differences between beef luncheon and the other products which had no significant differences between them (Table 6).

These results are lower than those been recorded by (Ramadhan et al., 2011) and (Al-Bahouh et al., 2012) in chicken burger and higher than those been recorded by (Prayson et al., 2008) in beef burger.

Table 4: Mean values of ash content in the examined meat product samples with their acceptability according to the Egyptian standards

\begin{tabular}{|c|c|c|c|c|c|c|}
\hline \multirow[b]{2}{*}{ Meat products } & \multirow[b]{2}{*}{ Mean \pm SE } & \multirow[b]{2}{*}{ EOS $^{*}$} & \multicolumn{2}{|c|}{ Accepted samples } & \multicolumn{2}{|c|}{ Unaccepted samples } \\
\hline & & & No & $\%$ & No & $\%$ \\
\hline \multirow[t]{2}{*}{ Beef luncheon } & $3.07 \pm 0.11^{\mathrm{a}}$ & Not more than $3.5 \%$ & & & & \\
\hline & & EOS* $^{*}(1114 / 2005)$ & 22 & 88 & 3 & 12 \\
\hline Beef burger & $4.01 \pm 0.11^{\mathrm{b}}$ & - & - & - & - & - \\
\hline \multirow{2}{*}{ Chicken luncheon } & $3.40 \pm 0.09^{c}$ & Not more than $3.5 \%$ & & & & \\
\hline & & $\operatorname{EOS}^{*}(1696 / 2005)$ & 12 & 48 & 13 & 52 \\
\hline \multirow[t]{2}{*}{ Chicken burger } & $3.17 \pm 0.12^{\mathrm{ac}}$ & Not more than $2.5 \%$ & & & & \\
\hline & & EOS* $^{*}(2910 / 2005)$ & 4 & 16 & 21 & 84 \\
\hline
\end{tabular}

EOS $*$ = Egyptian Organization for Standardization (EOS, 2005)

Means with the same letter are not significant difference $(\mathrm{P}<0.05)$

Table 5: Mean values of carbohydrate content in the examined meat product samples with their acceptability according to the Egyptian standards

\begin{tabular}{|c|c|c|c|c|c|c|}
\hline \multirow[b]{2}{*}{ Meat products } & \multirow[b]{2}{*}{ Mean \pm SE } & \multirow[b]{2}{*}{ EOS $^{*}$} & \multicolumn{2}{|c|}{ Accepted samples } & \multicolumn{2}{|c|}{ Unaccepted samples } \\
\hline & & & No & $\%$ & No & $\%$ \\
\hline Beef luncheon & $20.49 \pm 1.26^{\mathrm{a}}$ & - & - & - & - & - \\
\hline Beef burger & $6.29 \pm 0.64^{b}$ & Not more than $10 \%$ & & & & \\
\hline EOS $^{*}(1688 / 2005)$ & 20 & 80 & 5 & 20 & & \\
\hline Chicken luncheon & $12.63 \pm 0.49^{c}$ & - & - & - & - & - \\
\hline Chicken burger & $13.49 \pm 0.66^{c}$ & - & - & - & - & - \\
\hline
\end{tabular}

EOS * = Egyptian Organization for Standardization (EOS, 2005)

Means with the same letter are not significant difference $(\mathrm{P}<0.05)$. 
Ali M. Ahmed et al. / American Journal of Animal and Veterinary Sciences 2020, 15 (2): 145.152 DOI: 10.3844/ajavsp.2020.145.152

Table 6: Mean values of meat content in the examined meat product samples with their acceptability according to the Egyptian standards

\begin{tabular}{|c|c|c|c|c|c|c|}
\hline \multirow[b]{2}{*}{ Meat Products } & \multirow[b]{2}{*}{ Mean \pm SE } & \multirow[b]{2}{*}{ EOS $^{*}$} & \multicolumn{2}{|c|}{ Accepted samples } & \multicolumn{2}{|c|}{ Unaccepted samples } \\
\hline & & & No & $\%$ & No & $\%$ \\
\hline \multirow{2}{*}{ Beef luncheon } & $26.05 \pm 3.84^{\mathrm{a}}$ & Not less than $80 \%$ & & & & \\
\hline & & EOS* $^{*}(1114 / 2005)$ & 0 & 0 & 25 & 100 \\
\hline \multirow[t]{2}{*}{ Beef burger } & $47.16 \pm 2.99^{b}$ & Not less than $60 \%$ & & & & \\
\hline & & EOS* $^{*}(1688 / 2005)$ & 5 & 20 & 20 & 80 \\
\hline \multirow{2}{*}{ Chicken luncheon } & $49.67 \pm 2.34^{b}$ & Not less than $80 \%$ & & & & \\
\hline & & EOS* $^{*}(1696 / 2005)$ & 0 & 0 & 25 & 100 \\
\hline \multirow[t]{2}{*}{ Chicken burger } & $44.14 \pm 2.70^{b}$ & Not less than $60 \%$ & & & & \\
\hline & & EOS* $^{*}(2910 / 2005)$ & 3 & 12 & 22 & 88 \\
\hline
\end{tabular}

EOS * = Egyptian Organization for Standardization (EOS, 2005)

Means with the same letter are not significant difference $(\mathrm{P}<0.05)$.

Table 7: Correlation coefficient between protein content and meat content

\begin{tabular}{lll}
\hline & Protein & Meat content \\
\hline Protein & 1 & $+0.986^{* *}$ \\
Meat Content & $+0.986^{* *}$ & 1 \\
\hline
\end{tabular}

**. Correlation is significant at the 0.01 level (2-tailed).

Table 8: Correlation coefficient between moisture content and fat content

\begin{tabular}{lll}
\hline & Moisture & Fat \\
\hline Moisture & 1 & $-0.633^{* *}$ \\
Fat & $-0.633^{* *}$ & 1 \\
\hline$* *$. Correlation is significant at the 0.01 level (2-tailed)
\end{tabular}

By comparing the results with the Egyptian Standards (EOS, 2005), it is evident that $100 \%, 80 \%, 100 \%$ and $88 \%$ of beef luncheon, beef burger, chicken luncheon and chicken burger, respectively were unaccepted based on their meat content which were revealed in Table 6. The low meat content of the examined products could be contributed to the presence of fat and the replacement of expensive meat protein by cheap binders and fillers (Babji et al., 2000).

The statistical results showed that the Pearson's correlation between protein and meat content was positive and significant at the 0.01 level $\left(R^{2}=0.975\right)$ as shown in Table 7. While Pearson's correlation between moisture and fat is negative and significant at the 0.01 level $\left(R^{2}=-0.759\right)$ as shown in Table 8 .

\section{Conclusion}

The present study showed a significant difference in quality attributes between examined meat products. Most of them were lower in fat, protein and meat contents and higher in carbohydrate and moisture contents compared to the Egyptian Standards. It is quite evident from our study that the food industry is non-conferment with the regulatory requirements for meat quality standards.

\section{Acknowledgment}

All author acknowledged the technical support provided by Food Hygiene Department and Poultry disease Department staff members, Faculty of Veterinary Medicine, Suez Canal University

\section{Author's Contributions}

All authors equally contributed in this work.

\section{Ethics}

The experiment approved by Suez canal university ethical committee

\section{References}

Abd-Elhak, N.A., S.E. Ali and N.L. Zaki, 2014. Innovative modification of traditional burger. Egypt. J. Agric. Res., 92: 995-1008.

Abdelmoety, M., Y. Alyousef, A.A. Sayed and W. Elfeil, 2019. Evaluation of the antibody response of two local Saudi lines and commercial chickens vaccinated against Newcastle diseases virus and infectious bursal disease virus. Scientific J. King Faisal Univ., 20: 105-113.

Abouelmaatti, R.R., A.M. Algammal, X. Li, J. Ma and E.A. Abdelnaby et al., 2013. Cloning and analysis of Nile tilapia Toll-like receptors type-3 mRNA. Central Eur. J. Immunol., 3: 277-282.

Ahmad, A.M., H.A. Abdelrahman and H.M. Tolba, 2015. Nutritional quality of partially processed chicken meat products from Egyptian and Saudi Arabia markets. Proceedings of the Conference of Food Safety, Suez Canal University, Suez Canal University, Ismailia, Egypt, pp: 8-13.

Ahmed, A.E.A.A., E.M. El-Saied, A.H. Mahmoud, M.I.A. El-Hamied and A.M. Abd-Elmoteleb, 2016. Identification of donkey and pig meat in fresh minced beef mixtures by the polymerase chain reaction. 
Al-Bahouh, M.E., S.F. Al-Zenki, H. Alomirah, B. AlFailee and T. Al-Mutairi et al., 2012. Conformity of labeling into real composition of local and imported chicken burgers sold in the state of Kuwait. Int. J. Poultry Sci., 11: 529-535.

DOI: $10.3923 /$ ijps.2012.529.535

Al-Dughaym, A. and G. Altabari, 2010. Safety and quality of some chicken meat products in Al-Ahsa markets-Saudi Arabia. Saudi J. Biol. Sci., 17: 37-42.

Ali, A., 2011. Effect of some nutritional additives on the quality and formulation cost of beef burger. Cairo University, Egypt.

Ayoub, M.A., W. Elfeil, D.E. Boraey, H. Hammam and M.A. Nossair, 2019. Evaluation of some vaccination programs in protection of experimentally challenged broiler chicken against Newcastle disease virus. Am. J. Anim. Vet. Sci., 14: 197-206.

Babji, A.S., S. Jaksa, M. Yusof and S. Chempaka, 2000. Quality assessment of local and franchise beef and chicken burgers. Pertanika J. Tropical Agric. Sci., 23: 103-112.

Cornejo, F. and P. Chinachoti, 2003. NMR in foods: Opportunity and challenges. Royal Society Chem., 286: 25-37. DOI: 10.1039/9781847551269-00025

Diab, M.S., M.S. Abd-ElHafez, M.A. Ashry and W.K. Elfeil, 2019. Occurrence of avian influenza H5N1 among chicken, duck farms and human in Egypt. Am. J. Anim. Vet. Sci., 14: 26-32.

DOI: $10.3844 / a j a v s p .2019 .26 .32$

Edris, A., M. Hemmat, F. Shaltout, M. Elshater and F. Eman, 2012. Chemical profile of beef burger and beef luncheon. Benha Vet. Med. J., 23: 109-115.

Eid, H.I., A.M. Algammal, S.A. Nasef, W.K. Elfeil and G.H. Mansour, 2016. Genetic variation among avian pathogenic $E$. coli strains isolated from broiler chickens. Asian J. Anim. Vet. Adv., 11: 350-356.

Eid, H.M., A.M. Algammal, W.K. Elfeil, F.M. Youssef and S.M. Harb et al., 2019. Prevalence, molecular typing and antimicrobial resistance of bacterial pathogens isolated from ducks. Vet. World, 12: 677-683. DOI: 10.14202/vetworld.2019.677-683

El-Tahan, F.H., A.F. Abd El-Salam and M.H. El Tahan, 2006. Microbiological and chemical properties in chicken products collected from local markets. J. Agric. Sci. Mansoura Univ., 9: 989-997.

Elfeil, W.K., R.R. Abouelmaat, C. Sun, W. Han and X. Li et al., 2012. Identification, cloning, expression of a novel functional anas platyrhynchos mRNA TLR4. J. Anim. Vet. Adv., 11: 1727-1733.

Elhady, M.A., A. Ali, W.H. Kilany, W.K. Elfeil and H. Ibrahim et al., 2018. Field Efficacy of an attenuated infectious bronchitis variant 2 virus vaccine in commercial broiler chickens. Vet. Sci., 5: 1-9.

Eman, M., 2009. Chemical and nutritional criteria of some camel products. Veterinary Medicine, Benha Univrsity.
Enany, M.E., A.M. Algammal, A.M. Hanora, G.I. Shagar and W.K. Elfeil et al., 2018. Molecular typing and evaluation of Sidr honey inhibitory effect on virulence genes of MRSA strains isolated from catfish in Egypt. Pak. J. Pharm. Sci., 31: $1865-1870$.

EOS, 2005. Egyptian organization for standardization and quality control. Egyptian Standards for Poultry Meat Products, Egypt.

Erwanto, Y., M. Abidin and A. Rohman, 2012. Pig species identification in meatballs using polymerase chain reaction-restriction fragment length polymorphism for Halal authentication. Int. Food Res. J., 19: 901-906.

Farouk, M.M., 2013. Advances in the industrial production of halal and kosher red meat. Meat Sci., 95: 805-820. DOI: 10.1016/j.meatsci.2013.04.028

Fawzy, M., R.R. Ali, W.K. Elfeil, A.A. Saleh and W.H. Mady et al., 2020. Efficacy of inactivated velogenic Newcastle disease virus genotype VII vaccine in broiler chickens. Vet. Res. Forum.

Fernández-López, J., S. Jiménez, E. Sayas-Barberá, E. Sendra and J. Pérez-Alvarez, 2006. Quality characteristics of ostrich (Struthio camelus) burgers. Meat Sci., 73: 295-303.

DOI: 10.1016/j.meatsci.2005.12.011

Hamzah, A., S.A. Mutalib and A.S. Babji, 2014. Porcine DNA detection in finished meat products using different mitochondrial DNA (mt-DNA) on polymerase chain reaction. J. Nutrit. Food Sci., 4: 6-6. DOI: $10.4172 / 2155-9600.1000323$

Hargin, K., 1996. Authenticity issues in meat and meat products. Meat Sci., 43: 277-289.

DOI: 10.1016/0309-1740(96)00072-1

Ibrahim, M.A., M.F. Salama and A.A. Hussein, 2011. Production of functional low-fat chicken burger. Aust. J. Basic Applied Sci., 5: 3149-3154.

Jecan, C., M. Mihaiu, S.D. Dan, A. Lapusan and I.V. Cordis et al., 2013. Effect of fat type on chemical and quality attributes of chicken burgers. Vet. Med., 70: 249-252.

Joly, G. and B. Anderstein, 2009. Starches. In: Ingredients in Meat Products, Tarté, R. (Ed.), Springer, New York, pp: 25-55.

Kassem, M.G. and M. Emara, 2010. Quality and acceptability of value-added beef burger. World J. Dairy Food Sci., 5: 14-20.

Kirk, S. and R. Sawyer, 1991. Pearson's composition and analysis of foods. Longman Group Ltd.

Lawrie, R., 1998. Lawrie's Meat Science. 6th Edn., Woodhead Publishing Limited, Cambridge, England.

Moghazy, E., 1999. Reduced fat sausage as affected by using fat replacers, natural beef flavor and collagen casings. Egypt. J. Agric. Res., 77: 873-889. 
Pearson, A. and T. Gillette, 1996. Processed meats. New York Albany, Bonn, Boston, London.

Prayson, B., J.T. McMahon and R.A. Prayson, 2008. Fast food hamburgers: what are we really eating? Annals Diagnostic Pathol., 12: 406-409. DOI: 10.1016/j.anndiagpath.2008.06.002

Rady, M., N. Ezz-El-Din, K.F. Mohamed, S. Nasef and A. Samir et al., 2020. Correlation between ES $\beta$ L Salmonella serovars isolated from broilers and their virulence genes. J. Hellenic Vet. Med. Society.

Ramadhan, K., N. Huda and R. Ahmad, 2011. Physicochemical characteristics and sensory properties of selected Malaysian commercial chicken burgers. Int. Food Res. J., 18: 1349-1357.

Roostita, L.B., H.A.W. Lengkey, L. Suryaningsih, O. Rachmawan et al., 2014. Beef meatballs adulteration tests with real time quantitative PCR detection for halal authentication-case studies sellers at traditional market and Small Medium Enterprises (SMEs) merchants in Indonesia. AgroLife Scientific J., 3: 66-68.

SPSS, 2007. SPSS for windows, Version 16.0. SPSS Inc., Chicago.

Sedeik, M.E., A.M. Awad, H. Rashed and W.K. Elfeil, 2018. Variations in pathogenicity and molecular characterization of Infectious Bursal Disease Virus (IBDV) in Egypt. Am. J. Anim. Vet. Sci., 13: 76-86.

SPSS, 2007. SPSS for Windows, version 16.0. SPSS Inc., Chicago.
Sultan, H.A.E., A.M. Arafa, M. Talaat, A.A.E.R. Gaballa and W.H. Kilany et al., 2019a. Efficacy of clade2. 3.2 H5-recombinant Baculovirus vaccine in protecting Muscovy and Pekin ducks from clade 2.3. 4.4 H5N8 highly pathogenic avian influenza infection. Avian Dis., 63: 219-229.

DOI: 10.1637/0005-2086-63.1.219

Sultan, H.A., A. Ali, W.K. El Feil, A.H.I. Bazid and M.A. Zain El-Abideen et al., 2019b. Protective efficacy of different live attenuated infectious bronchitis virus vaccination regimes against challenge with IBV variant-2 circulating in the middle east. Frontiers Vet. Sci., 6: 341-341. DOI: 10.3389/fvets.2019.00341

Sultan, H.A., S. Talaat, W.K. Elfeil, K. Selim and M. Kutkat et al., 2020. Protective efficacy of Newcastle disease virus genotype VII-matching vaccine in commercial layers. Poult. Sci., 99: 1275-1286. DOI: 10.1016/j.psj.2019.10.063

Suman, S. and B. Sharma, 2003. Effect of grind size and fat levels on the physico-chemical and sensory characteristics of low-fat ground buffalo meat patties. Meat Sci., 65: 973-976.

DOI: 10.1016/S0309-1740(02)00313-3

Turhan, S., H. Temiz and I. Sagir, 2007. Utilization of wet OKARA in low-fat beef patties. J. Muscle Foods, 18: 226-235.

DOI: $10.1111 /$ j.1745-4573.2007. 00081.x 